\title{
ANALYSIS OF THE LEADING SECTOR AND THE EFFECT OF THE ECONOMIC GROWTH: A CASE STUDY IN PAKPAK BHARAT REGENCY, INDONESIA
}

\author{
Dinar Melani Hutajulu \\ Graduate Student State University of Medan \\ E-mail :dinarmelani@gmail.com \\ M. Nasir \\ Lecturer State University of Medan \\ E-mail : muhammadnasir8@gmail.com \\ Arwansyah \\ Lecturer State University of Medan \\ E-mail : Arwansyah63@gmail.com
}

\section{(Received: May 2018; Accepted: July 2018)}

\begin{abstract}
Pakpak Bharat Regency is an area with the lowest Gross Regional Domestic Product and Income percapita from 33 regency/city in North Sumatera Province. Because of this problem, to be important to know how the base sectors can improve the economy of Pakpak Bharat Regency. In this research, the study aims: (1) To know the base sectors in the economy of Pakpak Bharat Regency (2) To know the sector clasification of Gross Regional Domestic Product (GRDP) in Pakpak Bharat Regency (3) To know how the base sectors effect the Gross Regional Domestic Product of Pakpak Bharat Regency.

The data used in this study is secondary data and readings related to research. The tests used in this study are Klassen Typology, Location Quotient, and Least Square test. The research finds that: (1) the economics of Pakpak Bharat Regency is divided into several quadrants, is advanced and rapidly growing sectors (Quadrant I), advanced but depressed sectors (Quadrant II), potential sector (Quadrant III), and lagging sector (Quadrant IV). (2) sectors classified as advanced sectors in Quadrant I and Quadrant II (amounting to 4 sectors) are basic sectors in Pakpak Bharat Regency with LQ>1. (3) there is a positive and significant influence between the base sector on the GRDP of Pakpak Bharat Regency.
\end{abstract}

Keywords: Leading Sector, Typology of Sector, Regional Development

JEL Classification: C22, O10, R11, R58

\section{Introduction}

Economic development is essentially a business undertaken by the government with the goal of a community of a region has a better level of welfare and a better economy. Economic development is defined as a continuous process in processing 
Hutajulu D.N, Nasir, M., Arwansyah (2018)

Analysis of the leading sector and the effect of the economic growth: a case study in Pakpak Bharat Regency, Indonesia

the existing economic resources to achieve the goal of people's welfare (Frisdiantara,2016). In achieving economic development, there are three macro indicators that serve as a measure of development progress. The three indicators are growth rate, employment and price stability (Mankiw, 2006).

Basically, regional economic development can't be separated in relation to national development, one of the national development goals of Indonesia is to create economic growth and equitable development results, including the even distribution of income between regions (regions). Growth and economic development will encourage prosperity and prosperity of the people. One measure of the most important prosperity is income (Tarigan, 2009).

Analyzing the area as well as discussing an area will not be separated from discussing the income level of the people in the area. In this case, GRDP is often used to view the income of the community. By calculating the GRDP carefully and accurately, both based on current and constant prices, some conclusions can be drawn about the success of development in a region, showing the rate of economic growth representing increased production in various sectors of the existing business field. The GRDP picture showing the rate of economic growth reflects the income generated by the economic sectors in the region. Below is the Figure of growth rate of Gross Regional Domestic Product (GRDP) of Pakpak Bharat Regency.

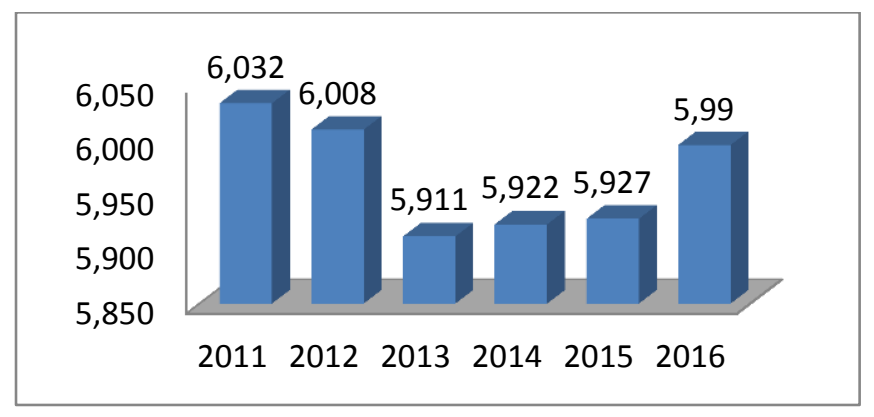

Figure. 1 : Growth Rate of Gross Regional Domestic Product (GRDP) of Pakpak Bharat Regency based on Constant Price 2010 from 2011-2016 (in Percent) Source : Central Bureau of Statistic of Pakpak Bharat Regency

Based on Figure 1, it is seen that the economy in 2010 to 2011 is still better than the year after. When viewed from the perspective of per capita income Pakpak Bharat compared with several other Regency around. It also shows that Pakpak Bharat Regency has the lowest per capita income from 2012-2015. The per capita income of Pakpak Bharat Regency is only about 13 million to 14 million in a year,

38 Sciendo Studia Universitatis "Vasile Goldis" Arad. Economics Series Vol 28 Issue 3/2018 ISSN: 1584-2339; (online) ISSN: $2285-3065$

Web: publicatii.uvvg.ro/index.php/studiaeconomia.Pages $37-49$ 
Hutajulu D.N, Nasir, M., Arwansyah (2018)

Analysis of the leading sector and the effect of the economic growth: a case study in Pakpak Bharat Regency, Indonesia

ie in 2012 (Rp13.354.111), 2013 (Rp13.845.113), 2014 (Rp14.359.614) and 2015 (Rp14.877.845).

According to North (Sjafrizal, 2008) states that "the economic growth of a region is basically determined by the magnitude of competitive advantage owned by the region concerned". If a particular region can encourage the growth of economic sectors that have a competitive advantage as a Base for export activities, the region's economic growth will increase rapidly. This is in line with Stimson et al (2013) assertion that the export base theory approach discussed earlier regional economic development as a result of the expansion of exports to other regions.

Pakpak Bharat Regency basically still need a special study on the economy. It is necessary to know in more detail which sectors can be a driver of economic growth as well as which commodity can become a superior commodity and competitive. If Pakpak Bharat regency develops without seeing potentials in the region, growth and regional development will be less than optimal. This research needs to be done in order to push the economy of Pakpak Bharat Regency in the future to a better direction.

\section{Literature review}

The economic growth of a region is basically determined by the amount of competitive advantage possessed by the region concerned (Sjafrizal, 2012). If a particular region can encourage the growth of sectors that have a competitive advantage as a Base for export activities, the region's economic growth will increase rapidly. Blair \& Carroll (2009) also states that the export-base theory of growth is grounded in the idea that a local economy should increase its monetary inflow is to increase exports. On the other hand, Kilkenny \& Partridge (2008) the export base model states that development depends on production activities that sell products outside the region. It is commonly assumed by rural economic development proponents.

In the theory of economic base, the economic growth rate of a region is determined by the large increase in exports from the region. Economic activity is classified on a Base and Non Base, as well as base activities that can encourage economic growth of the region (Tarigan, 2009). Furthermore, McCann (2013) states that the basic sector and the non-basic sectors are primarily on economic conditions external to the local economy, while the non-basic sector is made up of the sectors performance depends primarily on the economic conditions internal to the local economy.

Regional economic development is a process carried out jointly between the local government and the community in managing the various natural resources that exist in the area. Stimson, et al. (2006) states that regional economic 
Hutajulu D.N, Nasir, M., Arwansyah (2018)

Analysis of the leading sector and the effect of the economic growth: a case study in Pakpak Bharat Regency, Indonesia

development is the application of economic processes and resources available to a region that results in the sustainable development of, and desired economic outcomes for a region and that meet the values and expectations of business, of residents and of visitors.

The community basically has an important role in improving and promoting the region through increasing activity that support economic growth. As Karsinah, et al (2016) states that "regional economic development should enable local people to improve motivation to have a higher rate of economic growth through local economic potential empowerment by developing activities due to local strengths and the existing opportunities to improve community welfare" . In this case, the benchmark for the improvement of economic development is the economic growth of the region and the growth of the regional economy can be seen from how much increase of regional income of the region from time to time.

Regional development will not be separated from the level of income people in the area. Regional income is the level (amount) of the community's income in an area of analysis. The level of regional income can be measured from the total revenue of the region as well as the average income of the community in the region (Tarigan, 2009). Some of the parameters used to measure regional development are community income, employment, and income distribution

One of the concepts and definitions used in discussing regional income / added value is GRDP. Gross Domestic Product (GDP) at the national level as well as Gross Regional Domestic Product (GRDP) at the regional level illustrates the ability of a region to create added value at a given time (BPS, 2016). To find out whether people's purchasing power is increasing or not their income should be compared in constant value. It is on this Base that the GDP / GRDP should be presented in two forms, namely at current prices and at constant prices.

The development of the region aims to achieve a just and prosperous society, having a welfare that can be maintained over time (Ningsih, 2011). In the era of centralization, regional development planning is only as supporting the implementation of national policies and planning. According to Sjafrizal (2008) the grouping of development areas is based on two main criteria: (1) the similarity of the socio-economic conditions of the region (2) the inter-regional social and economic relation within the region concerned (Nodal Region). With this grouping, it is hoped that the determination of development areas will be more suitable to the needs of regional planning.

According to Lo \& Salih (2013) states In the planning environment, the growth pole approach has become a vital tool of public policy for decentralized development. Since the introduction of the concept by perroux, the approach has

40 Sciendo Studia Universitatis "Vasile Goldis" Arad. Economics Series Vol 28 Issue 3/2018 ISSN: 1584-2339; (online) ISSN: 2285 - 3065

Web: publicatii.uvvg.ro/index.php/studiaeconomia.Pages $37-49$ 
Hutajulu D.N, Nasir, M., Arwansyah (2018)

Analysis of the leading sector and the effect of the economic growth: a case study in Pakpak Bharat Regency, Indonesia

been popularized through theoretical and empirical writings in the field of regional development and planning.

But Sumitro's economic growth pattern (Erawati \& Yasa, 2010) states that "Economic growth is concerned with a single-dimensional development process and is measured by increasing output and income." Differences in economic growth will bring each region to form a growth pattern which can be classified in a particular classification to determine the relative economic potential of a region that can be seen using Klassen Tipology analysis. Sjafrizal (2008) stated Klassen Tipology analysis is an analytical tool used to find out how the picture of the pattern of economic growth structure of each region. The framework that will be used as the Base in this study are as follows:

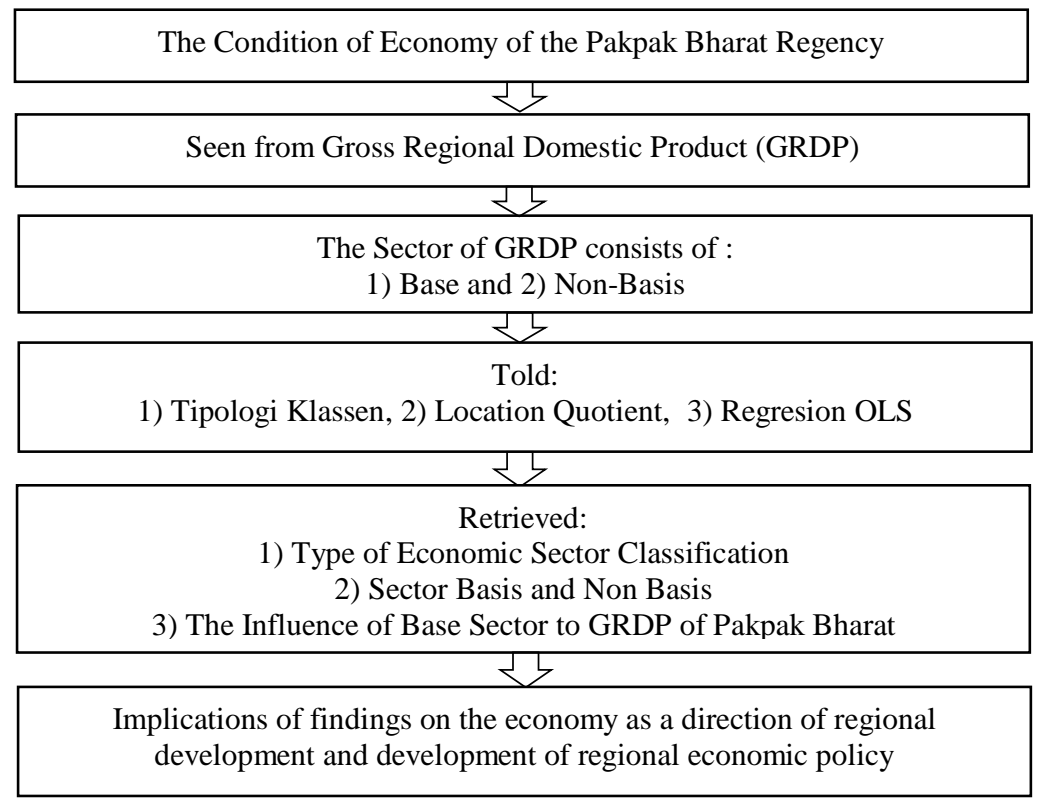

Figure 2. Conceptual Framework Design

\section{Research methodology}

This research was conducted in Pakpak Bharat Regency which became one of 33 regencies in North Sumatera. Pakpak Bharat was chosen as a research location because it is the region with the lowest GDP in North Sumatera Province and is also the region with the smallest per capita income compared to other areas around it. The data used in this study is secondary data obtained through certain sources and readings related to the research. 
Hutajulu D.N, Nasir, M., Arwansyah (2018)

Analysis of the leading sector and the effect of the economic growth: a case study in Pakpak Bharat Regency, Indonesia

This type of research is ex post facto research. According Sugiyono (2010) Ex Post facto is a research conducted to examine events that have occurred and then trace back to find out the factors that can cause the incident. To answer the problem in this research used some data analysis test. To know the classification of economic sector of region of Pakpak Bharat Regency used Klassen Tipology test. To see the comparison of the role of sector / industry in a region to the magnitude of the role of industry sector nationally, used the Location Quotation or LQ test.

Prior to hypothesis testing, a prerequisite test is performed on the classical assumption test: (1) Normality Test, (2) Autocorrelation Test, (3) Heterokedasticity Test, and (4) Newey-West HAC Standard Error Test. Furthermore, to see the significance between the influence of independent variables and dependent variables, used t test (partial), if the value of $t_{\text {count }}>$ $t_{\text {table }}$ or if the probability value $t<\mathrm{a}=0.05$. Then $H 0$ rejected, so the conclusion is independent variable partially significant affect variable dependent. Followed by Determination Coefficient test that aims to see the strength of the variation of independent variables in explaining the variation of dependent variables.

\section{Empirical results}

Based on the data obtained, Pakpak Bharat Regency has a total GRDP value which increases slowly every year. Below is a graph of increasing GRDP of Pakpak Bharat Regency based on constant 2010 prices.

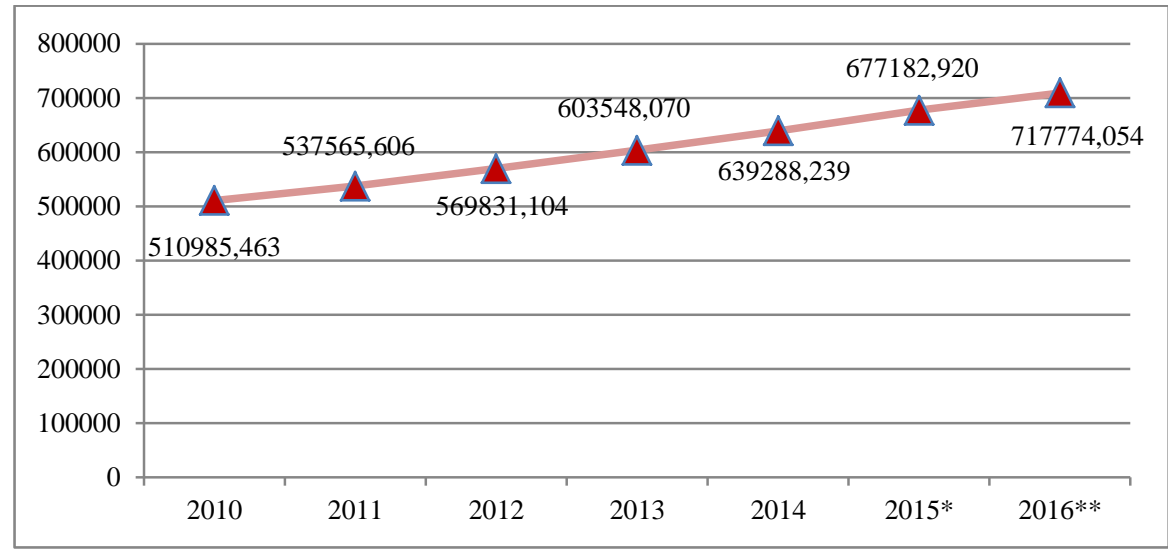

Figure 3. Total GRDP of Pakpak Bharat Regency based on 2010 Constant Price (Million Rupiah) 2010-2016

Source: Central Bureau of Statistic of Pakpak Bharat Regency 
Hutajulu D.N, Nasir, M., Arwansyah (2018)

Analysis of the leading sector and the effect of the economic growth: a case study in Pakpak Bharat Regency, Indonesia

If seen from the growth rate of Pakpak Bharat Regency, the growth rate from year to year from 2011 to 2016 shows a fluctuating number. To see the average income per capita received by each resident in each year can be seen in the graph below.

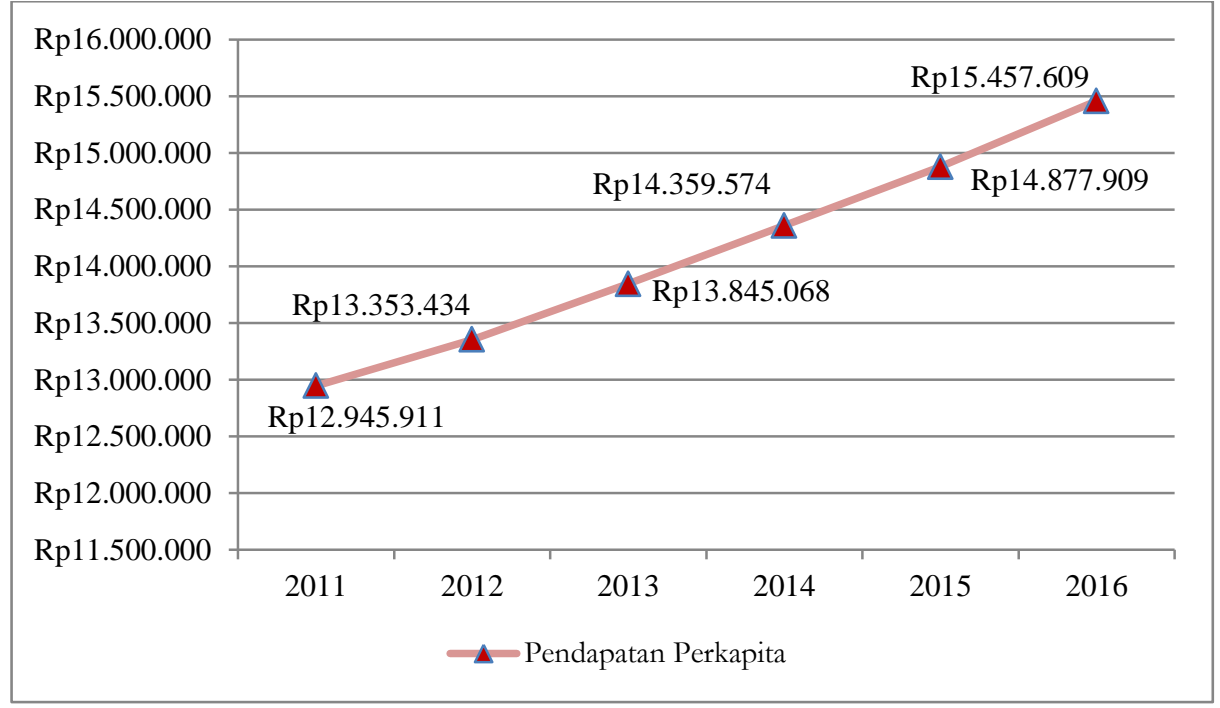

Figure 4. GRDP Per Capita at Constant 2010 Prices in Pakpak Bharat Regency from the Year 2011-2016

Source: Central Bureau of Statistic of Pakpak Bharat Regency

Based on GRDP per capita, the above Figure from year to year shows a relatively stable increase. In 2011, the GRDP per capita of the regency is Rp.12.945.911 up to 5 years later per capita GRDP only ranges from Rp.15.457.609.

Based on the results of Klassen Tipology analysis, there are four groups of economic sectors by using the growth rate value of each sector of business field and contribution value per sector. In doing this method required data in the form of GRDP on 2010 Constant Price Base Pakpak Bharat Regency according to the field of business year 2010-2016 as the area of analysis.

The results of Klassen Tipology analysis obtained the location of each sector according to their respective quadrant. There are 2 sectors in Quadrant I (advanced and fast growing sector), 2 sectors in Quadrant II (advanced but depressed sectors), 2 sectors in Quadrant III (potential sector or still developing), 
Hutajulu D.N, Nasir, M., Arwansyah (2018)

Analysis of the leading sector and the effect of the economic growth: a case study in Pakpak Bharat Regency, Indonesia

and 11 the other sectors are in Quadrant IV (relatively lagging sector). The clear quadrant division is shown in Table 1 below:

Table 1.

Classification of GRDP Sector of Pakpak Bharat Regency Year 2011-2016 Based on Klassen

\begin{tabular}{|l|l|}
\multicolumn{1}{|c|}{ Quadrant I } & \multicolumn{1}{c|}{ Quadrant II } \\
\hline $\begin{array}{l}\text { A Sophisticated and Growing Sector } \\
\text { (Developed Sector) } \\
\text { - Agriculture, Forestry and Fisheries Sectors } \\
\text { - Procurement of Electricity and Gas }\end{array}$ & $\begin{array}{l}\text { Sector Forward but Stressed (Stagnant Sector) } \\
\text { - The Provision of Accommodation and } \\
\text { Drinking Sectors } \\
\text { - Government Administration, Defense and Social } \\
\text { Security Sector Required }\end{array}$ \\
\hline \multicolumn{1}{|c|}{ Quadrant III } & \multicolumn{1}{c|}{ Quadrant IV } \\
\hline $\begin{array}{l}\text { Potential Sectors or Developable Sector } \\
\text { - Large and Retail Trade Sector, Car Repair } \\
\text { - Education Services Sector }\end{array}$ & $\begin{array}{l}\text { Underdeveloped Sector } \\
\text { - Mining and Quarrying Sector } \\
\text { - Processing Industry Sector } \\
\text { - Water Supply Sector, Waste } \\
\text { Management, Waste and Recycling } \\
\text { - Construction Sector } \\
\text { - Transportation and Warehousing Sector } \\
\text { - Information and Communications Sector } \\
\text { - Financial Services and Insurance Sector } \\
\text { - Real Estate Sector } \\
\text { - Company Service Sector } \\
\text { - Health Services Sector and Social Activities } \\
\text { - Other Service Sectors }\end{array}$ \\
\hline
\end{tabular}

The economic sector in a region is classified into two main categories, namely the base and non base sectors. Location Quotient analysis is used to know the economic sectors in PDPB of Pakpak Bharat Regency which can be classified into base and non base sector. The value of LQ > 1 means that the role of a sector in Pakpak Bharat Regency is more dominant than the same sector in North Sumatera Province and can be said to be the base sector, and vice versa for LQ $<1$. The result of Location Quotient analysis can be seen in the following Table 2 below.

From the average value of LQ in 2011 to 2016, there are 4 sectors that are categorized as the base sector, while 13 other sectors are declared as non base sector. After the classical assumption test, the data obtained shows that has been qualified for hypothesis testing. Hypothesis testing is done by comparing the $\mathrm{t}_{\text {count }}$ with $\mathrm{t}_{\text {table, }}$ at the level of $\alpha=0.05$ and $\mathrm{df}=22$ obtained the value of table of 2.0738 . 
Hutajulu D.N, Nasir, M., Arwansyah (2018)

Analysis of the leading sector and the effect of the economic growth: a case study in Pakpak Bharat Regency, Indonesia

Result of Location Quotient Analysis of Pakpak Bharat Regency

Table 2. Year 2011-2016

\begin{tabular}{|l|c|c|}
\hline \multicolumn{1}{|c|}{ Business Field } & Average & Description \\
\hline Agriculture, Forestry and Fisheries & 2,34 & Base \\
\hline Mining and excavation & 0,03 & Non Base \\
\hline Processing industry & 0,01 & Non Base \\
\hline Procurement of Electricity and Gas & 1,51 & Base \\
\hline Water Supply, Waste Management, Waste and Recycling & 0,69 & Non Base \\
\hline Construction & 0,76 & Non Base \\
\hline Large and Retail Trade, Automobile and Motorcycle Repair & 0,56 & Non Base \\
\hline Transportation and Warehousing & 0,46 & Non Base \\
\hline Provision of Accommodation and Eating and Drinking & 1,05 & Base \\
\hline Information and Communication & 0,31 & Non Base \\
\hline Financial Services and Insurance & 0,27 & Non Base \\
\hline Real Estate & 0,39 & Non Base \\
\hline Company Services & 0,02 & Non Base \\
\hline Mandatory Administration of Government, Defense and Social Security & 3,52 & Base \\
\hline Educational Services & 0,65 & Non Base \\
\hline Health Services and Social Activities & 0,48 & Non Base \\
\hline Other Services & 0,05 & Non Base \\
\hline
\end{tabular}

Table 3.

Adjusted R-squared Value Based on Data Processing by Using Eviews 6 Dependent Variable: PDRB

Method: Least Squares

Date: 02/10/18 Time: 19:22

Sample: 2011Q1 2016Q4

Included observations: 24

Newey-West HAC Standard Errors \& Covariance (lag truncation=2)

\begin{tabular}{|lrlrr|}
\hline \multicolumn{1}{c}{ Variable } & Coefficient & \multicolumn{1}{c|}{ Std. Error } & \multicolumn{1}{c|}{ t-Statistic } & \multicolumn{1}{c|}{ Prob. } \\
\hline \multicolumn{1}{c}{$\mathrm{C}$} & -11924.63 & 2724.358 & -4.377045 & 0.0002 \\
$\mathrm{X} 1+\mathrm{X} 2+\mathrm{X} 3+\mathrm{X} 4$ & 1.469076 & 0.025310 & 58.04342 & 0.0000 \\
\hline R-squared & 0.998082 & Mean dependent var & 156049.6 \\
Adjusted R-squared & 0.997995 & S.D. dependent var & 15895.38 \\
S.E. of regression & 711.7278 & Akaike info criterion & 16.05292 \\
Sum squared resid & 11144241 & Schwarz criterion & 16.15109 \\
Log likelihood & -190.6351 & Hannan-Quinn criter. & 16.07897 \\
F-statistic & 11450.07 & Durbin-Watson stat & 0.278543 \\
Prob(F-statistic) & 0.000000 & & \\
\hline \hline
\end{tabular}

While the value of $t$ count in table equal to 58,0434. Can be said $t_{\text {count }}=58.0434$ $>$ table $=2.0738$. Then Ho is rejected and $\mathrm{Ha}$ accepted. The value of significance on the independent variable is $0.000<\alpha=0.05$. From the above results can 
Hutajulu D.N, Nasir, M., Arwansyah (2018)

Analysis of the leading sector and the effect of the economic growth: a case study in Pakpak Bharat Regency, Indonesia

be concluded that the partial independent variables have a positive and significant influence on the dependent variable in the model of regression equation. In this study, the regression model experienced heterokedastisitas and autocorrelation problems that have been cured by regression model Newey West Standard Error (HAC). So the value of the coefficient of determination seen is the value of Adjusted R-squared which can be seen in the Table 3 above.

From the Table 3 above can be seen Adjusted R-squared value 0.997995 which means the strength of variable X_Base in explaining the GRDP variable is $99.79 \%$. While the rest of $0.21 \%$ explained by other factors not examined.

\section{Discussions}

Klassen Tipology analysis used in this research is able to know how to describe the pattern of economic growth structure of each region. As some studies have used Klassen Tipology Analysis in classifying the pattern of economic growth structure in an area (Fattah \& Rahman, 2013; Nikijuluw, 2013; Sinaga, 2015; Hariyanti \& Utha, 2016). The result of Klassen Tipology analysis shows that there are four groupings of economic sector by using growth rate value of each sector of business field and contribution value per sector.

On the other hand, the use of LQ analysis is best suited to find out which economic sectors can be categorized into basic and nonbased sectors. As some related studies have been done before (Hidayat, 2013; Supriharjo \& Hidayat, 2014; Kesuma \& Utama, 2015; Currie, 2017). Based on the result of LQ analysis calculation, there are 4 sectors that can be said as base sector because it has LQ > 1 . The sectors are: (1) agriculture sector, forestry and fishery, (2) electricity and gas procurement sector, (3) sector providing accommodation and eating, and (4) government administration, defense and compulsory social security. It can be said that the above four sectors are sectors that can promote regional economic growth. In line with the LQ scores, the four sectors have the capability to meet the needs within their region and are able to export various commodities as well as the result of their business out of Pakpak Bharat area.

Sumitro (1994) explains that economic growth is linked to the development process and is measured by increased output and income. Differences in economic growth will bring each region to form a growth pattern which can be classified in a particular classification. In this case pakpak bharat has found the right classification to trigger its economic growth and can be a growth pattern in improving the welfare of the surrounding community. The result of data analysisalso shows that the increase of base sector can increase Gross Domestic Regional Product (GDRP) of Pakpakl Bharat Regency. If associated with Export Base Theory introduced by Douglas C. North, the model equation estimation

46 Sciendo Studia Universitatis "Vasile Goldis" Arad. Economics Series Vol 28 Issue 3/2018 ISSN: 1584-2339; (online) ISSN: $2285-3065$

Web: publicatii.uvvg.ro/index.php/studiaeconomia.Pages $37-49$ 
Hutajulu D.N, Nasir, M., Arwansyah (2018)

Analysis of the leading sector and the effect of the economic growth: a case study in Pakpak Bharat Regency, Indonesia

results are in accordance with Export Base Theory. Where it is said that if a region is able to increase the sector in its area as a Base for export activities, then this will give a big enough impact for the local economy concerned.

Blair \& Carroll (2009) states that "The export-base theory of growth is grounded in the idea that a local economy must increase its monetary inflow is to increase exports". The above theory also says that the regional economy should increase the financial inflows to keep growing, the most appropriate way to increase the inflow of finance is to increase export activities. The exports carried out should be in the sector stated in the base sector. The result of hypothesis test shows that partially independent variable (base sector) has positive and significant influence on dependent variable (GRDP Pakpak Bharat Regency) in regression equation model obtained.

\section{Conclusions}

Based on the results of research, it can be concluded that:

1) The results of Klassen Tipology analysis divide into four sectors: (a) advanced and rapidly growing sector (Quadrant I) are agriculture, forestry and fishery sector and electricity and gas procurement sector. (b) advanced but depressed sector (Quadrant II) is the sector of accommodation and drinking water supply as well as the government administration, defense and compulsory social security sectors. (c) potential sectors (Quadrant III) of large and retail trade, auto and motorcycle repairs and education services sector, and (d) the remainder of the sector are left behind (Quadrant IV).

2) After 17 sectors were analyzed using Location Quotient analysis, it was found that sectors classified as advanced sectors in Quadrant I and Quadrant II (as many as 4 sectors) were the base sector in Pakpak Bharat Regency with $L Q>1$.

3) There is a positive and significant influence between the base sector to GRDP of

4) Pakpak Bharat Regency, based on a partial t test with a significance value < 0.05 .

5) The strength of $X \_B a s e$ variable (base sector) in explaining the GRDP variable of Pakpak Bharat Regency is $99.79 \%$, while the rest of $0.21 \%$ is explained by other factors not examined.

\section{References}

1. Blair, J.P. \& Carroll, M.C. 2009. Local Economic Development: Analysis, Practices and Globalization (2nd ed). Los Angeles: Sage Publications, Inc.

2. BPS. 2016 Provinsi Sumatera Utara Dalam Angka 2016. Medan: BPS Provinsi 
Hutajulu D.N, Nasir, M., Arwansyah (2018)

Analysis of the leading sector and the effect of the economic growth: a case study in Pakpak Bharat Regency, Indonesia

Sumatera Utara.

3. Currie, L. 2017. The "Leading Sector" Model of Growth in Developing Countries. Journal of Economic Studies. 1(1): 1-16.

4. Erawati, N.K. \& Yasa, I.N.M. 2010. Analisis Pola Pertumbuhan Ekonomi dan Sektor Potensial Kabupaten Klungkung. Jurnal Ekonomi Udayana. 3(1): 1-21.

5. Fattah, S. \& Rahman, A. 2013. Analysis of Regional Economic Development in the Regency/Municipality at South Sulawesi Province in Indonesia. Journal of Economic and Sustainable Development. 4(1): 1-9.

6. Frisdiantara, C. \& Mukhklis, I. 2016. Ekonomi Pembangunan: Sebuah Kajian Teoritis dan Empiris. Malang : Lembaga Penerbitan Universitas Kanjuruhan.

7. Haryanti, D. \& Utha, M.A. 2016. Analysis of Determinants Sectors Regional Development at 33 Provinces in Indonesia. OIDA Internasional Journal of Sustainable Development, (3): 11-32.

8. Hidayat, J.A.J. 2013. Analisis Struktur Perekonomian di Kota Manado. Jurnal EMBA. 1(3): 930-938.

9. Karsinah, K., Putri, P.I., Rahayu, K.N. \& Panjiputri, A.F. 2016. The profile of Pekalongan as Center of Economic Growth at Tangkallangka Strategic Areas. Semarang. International Journal of Economics and Financial Issues, 6(6): 105-109.

10. Kesuma, N.L.A. \& Utama, I.M.S. 2015. Analisis sektor unggulan dan pergeseran pangsa sektor-sektor ekonomi Kabupaten Klungkung. Universitas Udayana: E- Jurnal Ekonomi Pembangunan, 4(3):169-179.

11. Kilkenny, M. \& Partridge, M. 2008. Export Sectors and Rural Development. Journal of Department Agricultural, Environmental and Development Economics: 1-32.

12. Lo, F.C. \& Salih, K. 2013. Growth Pole Strategy and Regional Development Policy. New York: Pergamon Press, Ltd.

13. Mankiw, N. G. 2006. Makro Ekonomi Edisi Keenam. Jakarta: Erlangga.

14. McCann, Philip. 2013. Modern Urban and Regional Economics: Second Edition. Oxford University : Ashford Colour Press, Ltd.

15. Nikijuluw, J.B. 2013. Analisis Sektor Ekonomi Unggulan Kabupaten/Kota di Provinsi Maluku. Jurnal Ekonomi Cita Ekonomika, 7(2): 196-303.

16. Ningsih, E.G., 2011. Perencanaan Pembangunan Wilayah Berwawasan Lingkungan. http://ekaagustianingsih.blogspot.co.id/2011/04/perencanaan-pembangunanwilayah.html (diakses pada 03 April 2017).

17. Sinaga, D. 2015. Determination Analysis of Leading Economic Sector Againts Forming Region GDP in Simalungun. International Journal of Innovative Research in Management, 3(4) 1-12.

18. Sjafrizal. 2008. Ekonomi Regional: Teori dan Aplikasi. Jakarta: Niaga Swadaya.

19. Sjafrizal. 2012. Ekonomi Wilayah dan Perkotaan. Padang: Raja Grafindo Persada. Stimson, R.J., Stough, R.R. \& Roberts, B.H. 2013. Regional Economic Development: Analysis and Planning Strategy (Advances in Spatial Science). New York: Springer.

20. Sugiyono. 2010. Metode Penelitian Pendidikan, Pendekatan Kuantitatif, Kualitatif, dan $R \& D$. Bandung : Alfabeta

48 S sciendo Studia Universitatis "Vasile Goldis" Arad. Economics Series Vol 28 Issue 3/2018 ISSN: 1584-2339; (online) ISSN: 2285 - 3065

Web: publicatii.uvvg.ro/index.php/studiaeconomia.Pages $37-49$ 
Hutajulu D.N, Nasir, M., Arwansyah (2018)

Analysis of the leading sector and the effect of the economic growth: a case study in Pakpak Bharat Regency, Indonesia

21. Supriharjo, R. \& Hidayat, M.E. 2014. Identifikasi Sub Sektor Unggulan Kecamatan di Kabupaten Lombok Tengah. Jurnal Teknik Pomits Institut Teknologi Sepuluh Nopember, 3(1):16-20.

22. Tarigan, R. 2009. Ekonomi Regional: Teori dan Aplikasi, Edisi Revisi. Jakarta: Bumi Aksara. 